\title{
Engineering Escherichia coli to increase plasmid DNA production in high cell-density cultivations in batch mode
}

Gheorghe M Borja ${ }^{1}$, Eugenio Meza Mora², Blanca Barrón³, Guillermo Gosset², Octavio T Ramírez and Alvaro R Lara ${ }^{4 *}$

\begin{abstract}
Background: Plasmid DNA (pDNA) is a promising molecule for therapeutic applications. pDNA is produced by Escherichia coli in high cell-density cultivations (HCDC) using fed-batch mode. The typical limitations of such cultivations, including metabolic deviations like aerobic acetate production due to the existence of substrate gradients in large-scale bioreactors, remain as serious challenges for fast and effective pDNA production. We have previously demonstrated that the substitution of the phosphotransferase system by the over-expressed galactose permease for glucose uptake in E. coli (strain VH33) allows efficient growth, while strongly decreases acetate production. In the present work, additional genetic modifications were made to VH33 to further improve pDNA production. Several genes were deleted from strain VH33: the recA, deoR, nupG and endA genes were inactivated independently and in combination. The performance of the mutant strains was evaluated in shake flasks for the production of a $6.1 \mathrm{~kb}$ plasmid bearing an antigen gene against mumps. The best producer strain was cultivated in lab-scale bioreactors using $100 \mathrm{~g} / \mathrm{L}$ of glucose to achieve HCDC in batch mode. For comparison, the widely used commercial strain DH5a, carrying the same plasmid, was also cultivated under the same conditions.

Results: The various mutations tested had different effects on the specific growth rate, glucose uptake rate, and pDNA yields $\left(Y_{P / X}\right)$. The triple mutant $\mathrm{VH} 33 \Delta$ (recA deoR nupG) accumulated low amounts of acetate and resulted in the best $Y_{P / X}(4.22 \mathrm{mg} / \mathrm{g})$, whereas $Y_{P / X}$ of strain VH33 only reached $1.16 \mathrm{mg} / \mathrm{g}$. When cultivated at high glucose concentrations, the triple mutant strain produced $186 \mathrm{mg} / \mathrm{L}$ of pDNA, $40 \mathrm{~g} / \mathrm{L}$ of biomass and only $2.2 \mathrm{~g} / \mathrm{L}$ of acetate. In contrast, DH5a produced only $70 \mathrm{mg} / \mathrm{L}$ of pDNA and accumulated $9.5 \mathrm{~g} / \mathrm{L}$ of acetate. Furthermore, the supercoiled fraction of the pDNA produced by the triple mutant was nearly constant throughout the cultivation.

Conclusion: The pDNA concentration obtained with the engineered strain VH33 $\Delta$ (recA deoR nupG) is, to the best of our knowledge, the highest reported for a batch cultivation, and its supercoiled fraction remained close to $80 \%$. Strain VH33 $\Delta$ (recA deoR nupG) and its cultivation using elevated glucose concentrations represent an attractive technology for fast and efficient pDNA production and a valuable alternative to fed-batch cultivations of commercial strains.
\end{abstract}

Keywords: Plasmid DNA, DNA vaccines, Overflow metabolism, E. coli, Batch cultivation, Acetate

\footnotetext{
* Correspondence: alara@correo.cua.uam.mx

${ }^{4}$ Departamento de Procesos y Tecnología, Universidad Autónoma Metropolitana-Cuajimalpa, Artificios No. 40, Col. Miguel Hidalgo, Del. Álvaro Obregón, México, DF CP 01120, México

Full list of author information is available at the end of the article
} 


\section{Background}

Plasmid DNA (pDNA) is an attractive alternative for immunization and gene therapy against many infectious, genetic and acquired diseases [1]. The common host for pDNA production is the bacterium Escherichia coli. Several E. coli strains have been reported for pDNA production, such as DH5 $\alpha$ [2-4], DH5 [5], DH1 [6,7], JM108 [8]; SCS1-L [9] and DH10B [10]. Most of the strains used for pDNA production are selected by its previous use in laboratory-scale protocols [11,12] and may be not suitable for process-like conditions. For example, the typical challenges for high cell-density cultivations (HCDC) of E. coli remain as obstacles for the fast and efficient production of pDNA. Among them, aerobic acetate production is an important drawback, since it causes a loss of productivity and waste of carbon source [13]. Aerobic acetate production -known as overflow metabolism- results from an imbalance between glycolysis and tricarboxylic acids cycle [13,14]. Some of the strains commonly used for pDNA production present elevated overflow metabolism, including E. coli $\mathrm{DH} 5 \alpha$ and $\mathrm{DH} 1$ [9]. While the conventional way of avoiding overflow metabolism is reducing the glucose uptake in the so called fed-batch mode, the constant supply of glucose to the bioreactor requires additional equipment, results in a decrease of growth rate and frequently causes substrate gradients at the feeding zone in production bioreactors that trigger undesirable physiological effects [15-17]. We have previously demonstrated that the substitution of the natural glucose transport system (PTS) by a constitutively expressed galactose permease under the strong trc promoter in E. coli allows efficient growth by reducing the glucose uptake rate and consequently decreasing acetate production $[18,19]$. The modified strain, named VH33, has been tested for pDNA production using high initial glucose concentrations in order to reach high cell-densities in batch mode, yielding the double of pDNA per gram of cell $\left(\mathrm{Y}_{\mathrm{p} / \mathrm{x}}\right)$ than the parental strain, W3110 [20]. In order to increase carbon availability for nucleotide synthesis, the $p y k A$ gene (codifying for pyruvate kinase A) was inactivated in $\mathrm{VH} 33$, which resulted in a further increase of $70 \%$ of $\mathrm{Y}_{\mathrm{p} / \mathrm{x}}$ [21]. The possibility of cultivating VH33 strains and derivatives at high celldensity in batch mode is a simple and valuable alternative to fed-batch mode for the fast and efficient production of pDNA both, at early-stages of product development and at technical scale.

Notwithstanding the higher production of VH33 and VH33 $\Delta p y k A$, compared to W3110, its production levels remain low if compared to commercial strains like $\mathrm{DH} 5 \alpha$. In the present work, the genes $\operatorname{end} A, \operatorname{rec} A$, $\operatorname{deo} R$ and nupG were inactivated in strain VH33 independently and in combination, in order to increase pDNA yields. The best engineered strain was cultivated in batch mode using $100 \mathrm{~g} / \mathrm{L}$ of initial glucose to attain high celldensities.

\section{Results and discussion}

Evaluation of the engineered strains in shake flasks

Initially, the growth profiles and pDNA yields of strains W3110 and VH33 were evaluated in shake flasks as described in the Materials and Methods section. Due to the good productivity and wide use of strain DH5 $\alpha$, it was also evaluated and used for comparison. When grown in shake flask, W3110 reached $1.14 \pm 0.10 \mathrm{mg} / \mathrm{L}$ of pDNA (Figure 1A) and produced $0.32 \pm 0.03 \mathrm{~g} / \mathrm{L}$ of acetate (Figure 1B). Strain VH33 produced $2.78 \pm 0.10 \mathrm{mg} / \mathrm{L}$
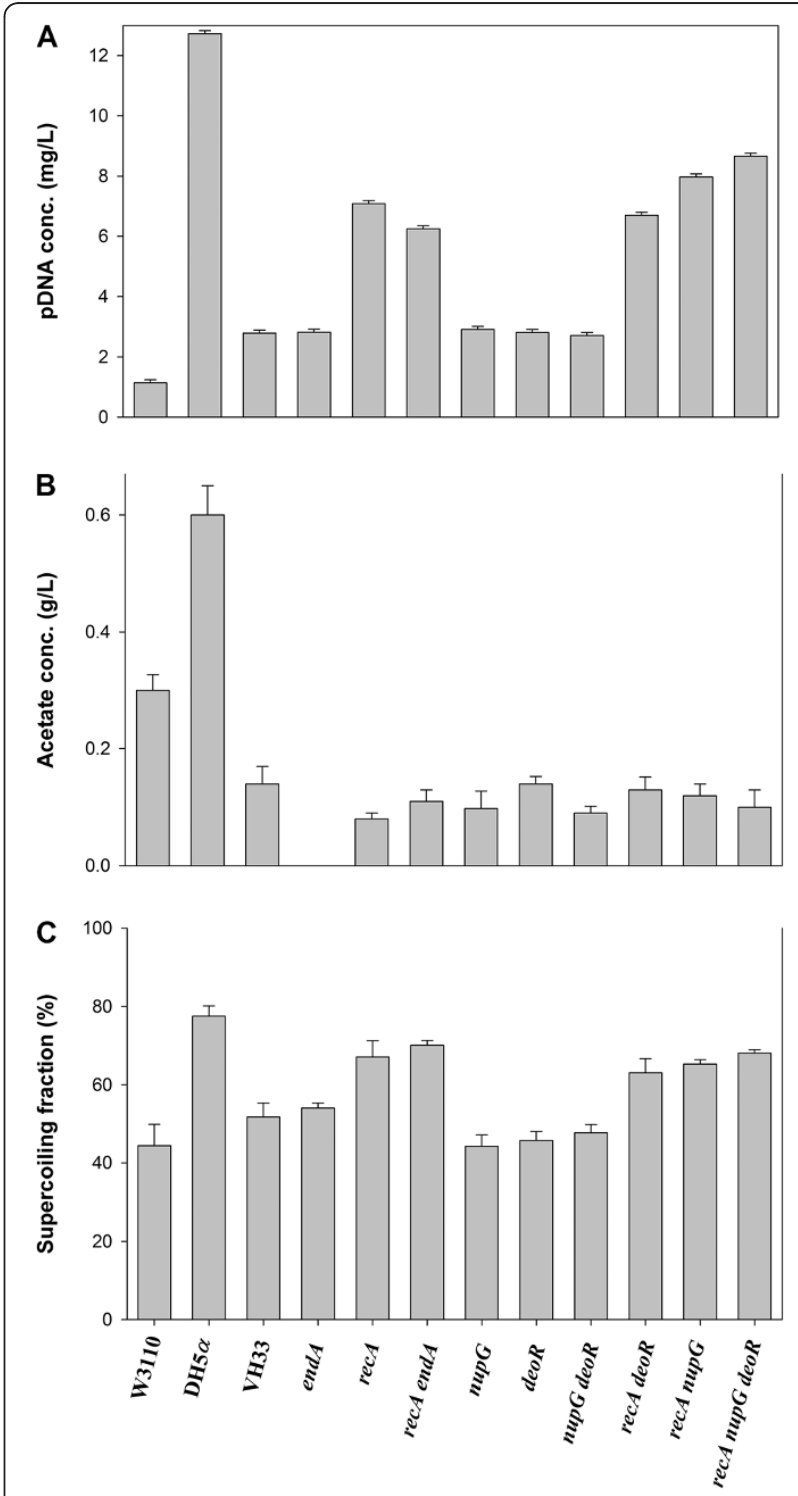

Figure 1 pDNA concentration (A), Acetate concentration (B) and PDNA supercoiled fraction (C) in shake flask cultivation of the different strains evaluated. Error bars show the standards deviation between triplicates. 
of pDNA and only $0.14 \pm 0.01 \mathrm{~g} / \mathrm{L}$ of acetate (Figure $1 \mathrm{~A}$ and $1 \mathrm{~B})$. The commercial strain $\mathrm{DH} 5 \alpha$ produced $12.73 \pm 0.10 \mathrm{mg} / \mathrm{L}$ of pDNA, and accumulated a remarkably high amount of acetate, reaching up to $0.62 \pm 0.04 \mathrm{~g} / \mathrm{L}$ (Figure 1B). Regarding the supercoiled fraction, under shake flask conditions, $50 \%$ of the pDNA produced by strains W3110 and VH33 was supercoiled, whereas for DH5 $\alpha$ cultivations, the supercoiled fraction was around $80 \%$ (Figure 1C).

A series of VH33-based mutants were obtained and tested. First, mutations aimed at increasing the plasmid stability were performed. The gene end $A$, coding for a type I endonuclease was deleted, since it has been proposed that such a mutation increases the stability of pDNA [22,23]. As shown in Figure 1, neither the amount of pDNA nor the pDNA supercoiled fraction produced by VH33 $\Delta$ endA changed with respect to $\mathrm{VH} 33$, and no acetate was detected. These results imply that no relevant pDNA degradation occurs intracellularly in E. coli, and that the positive effect of endA deletion could be seen particularly during downstream operations, although this was not tested.

A second target gene was the $\operatorname{rec} A$, that codes for recombinase A. An important cause of plasmid instability is the formation of plasmid oligomers, which originates cells with low copy number. Oligomers can be formed by homologous recombination. In E. coli, the RecBCD and a variation of RecF pathways are responsible for recombination [24]. The latter requires the products of $r e c A, r e c F$, recJ, recO genes $[25,26]$. Recombination via RecBCD and RecF pathways is inactivated by mutations in $r e c A, r e c B, r e c C$ and $r e c D$ [27]. The formation and breakdown of oligomers is blocked by mutations in rec $A$ or $\operatorname{rec} F$ [28]. RecA has also a proteolytic activity that activates the Cop protein, a repressor of plasmid replication [27]. In general, it has been reported that recA mutants display higher stability [29] and often show a higher pDNA production than parental strains $[11,22,30]$.

As shown in Figure 1A, VH33 $\Delta$ recA produced $7.09 \pm 0.10 \mathrm{mg} / \mathrm{L}$ of pDNA, which is 6.2 times more pDNA than W3110 and 2.5 times more than VH33. Moreover, VH33 $\Delta$ recA retained a low overflow metabolism, since the acetate accumulated was only $0.08 \pm 0.01 \mathrm{~g} / \mathrm{L}$ (Figure 1B). Furthermore, the $r e c A$ mutation resulted in a pDNA supercoiled fraction of $68 \pm 8 \%$ (Figure 1C). It has been shown that RecA protein participates in the regulation on toposiomerase A gene $(\operatorname{top} A)$ [31]. Therefore, it is possible that recA mutants display a higher topoisomerase activity, which helps to explain the effect observed in VH33 $\Delta$ recA. Additionally, a double mutant VH33 $\Delta$ (recA endA) was obtained in order to evaluate a possible synergistic effect of both mutations. A shown in Figure 1, the double mutant produced slightly less pDNA $(6.25 \pm 0.10 \mathrm{mg} / \mathrm{L})$ than the single mutants, whereas the
pDNA supercoiled fraction and acetate accumulation was similar to VH33 $\Delta$ recA.

A second group of mutations were performed to increase the synthesis of nucleotides, since the availability of such building blocks could be a limiting factor for pDNA synthesis in E. coli. The target genes were deoR and nupG. The deoR gene codes for a protein that represses the expression of several genes of the deo operon that code for enzymes needed for deoxynucleotide synthesis. Strains lacking deoR display a higher level of thymine phosphorylase, phosphopentamutase and deoxyaldolase [32]. Therefore, it was expected that deoR mutants could produced more pDNA. Yet, no change with respect to VH33 was observed in pDNA production or acetate accumulation; whereas pDNA supercoiled fraction was lower when VH33 $\Delta$ deoR was evaluated (Figure 1C). The nupG gene codes for a protein involved in nucleotide transport and catabolism, participating in the regulation of genes involved in nucleotide synthesis. It has been shown that nupG mutants can produce significantly more purine nucleosides than parental strains [33]. Nevertheless, when nup $G$ was deleted in VH33, no change in pDNA production was observed (Figure 1A). Moreover, when both $\mathrm{deoR}$ and nupG mutations were combined in VH33, no positive effect was seen (Figure 1A). A double mutant VH33 $\Delta$ (recA deoR) was obtained. This strain produced $12 \%$ more pDNA $(7.98 \pm 0.10 \mathrm{mg} / \mathrm{L})$ than $\mathrm{VH} 33 \Delta \mathrm{rec} A$. In contrast, the double mutant VH33 $\Delta$ (recA nupG) produced the same amount of pDNA than VH33 $\Delta$ recA (Figure 1A). Finally, all the three mutations were incorporated in VH33. The triple mutant VH33 $\Delta$ (recA deoR nupG) produced $22 \%$ more pDNA $(8.67 \pm 0.10 \mathrm{mg} / \mathrm{L})$ than VH33 $\Delta$ recA, 300\% more than $\mathrm{VH} 33$ and $760 \%$ more than W3110 (Figure 1A). This implies that not only the deletion of genes involved in nucleotide catabolism are necessary to increase pDNA production, but also increasing the plasmid stability is needed to see a positive effect. Another important result is that the triple mutant strain maintained a very low overflow metabolism and that the pDNA produced was supercoiled in $70 \pm 5 \%$ (Figure 1C).

A comparison of the performance of the mutant strains is shown in Figure 2. Since the productivity of a process is given not only by the final concentration obtained, but also by the product yield $\left(\mathrm{Y}_{\mathrm{p} / \mathrm{x}}\right)$ and specific production rate $\left(q_{p}\right)$, such values were compared in relation with the specific growth rate $(\mu)$ for W3110, VH33 and all mutant strains. It is generally assumed that the specific growth rate of $E$. coli is inversely proportional to $Y_{p / x}$ (for a review on this issue, see [1]). However, such a correlation was not observed by for all the strains studied here. As shown in Figure 2A, strain VH33 grew slower $\left(0.37 \pm 0.01 \mathrm{~h}^{-1}\right)$ than W3110 $\left(0.61 \pm 0.01 \mathrm{~h}^{-1}\right)$ 


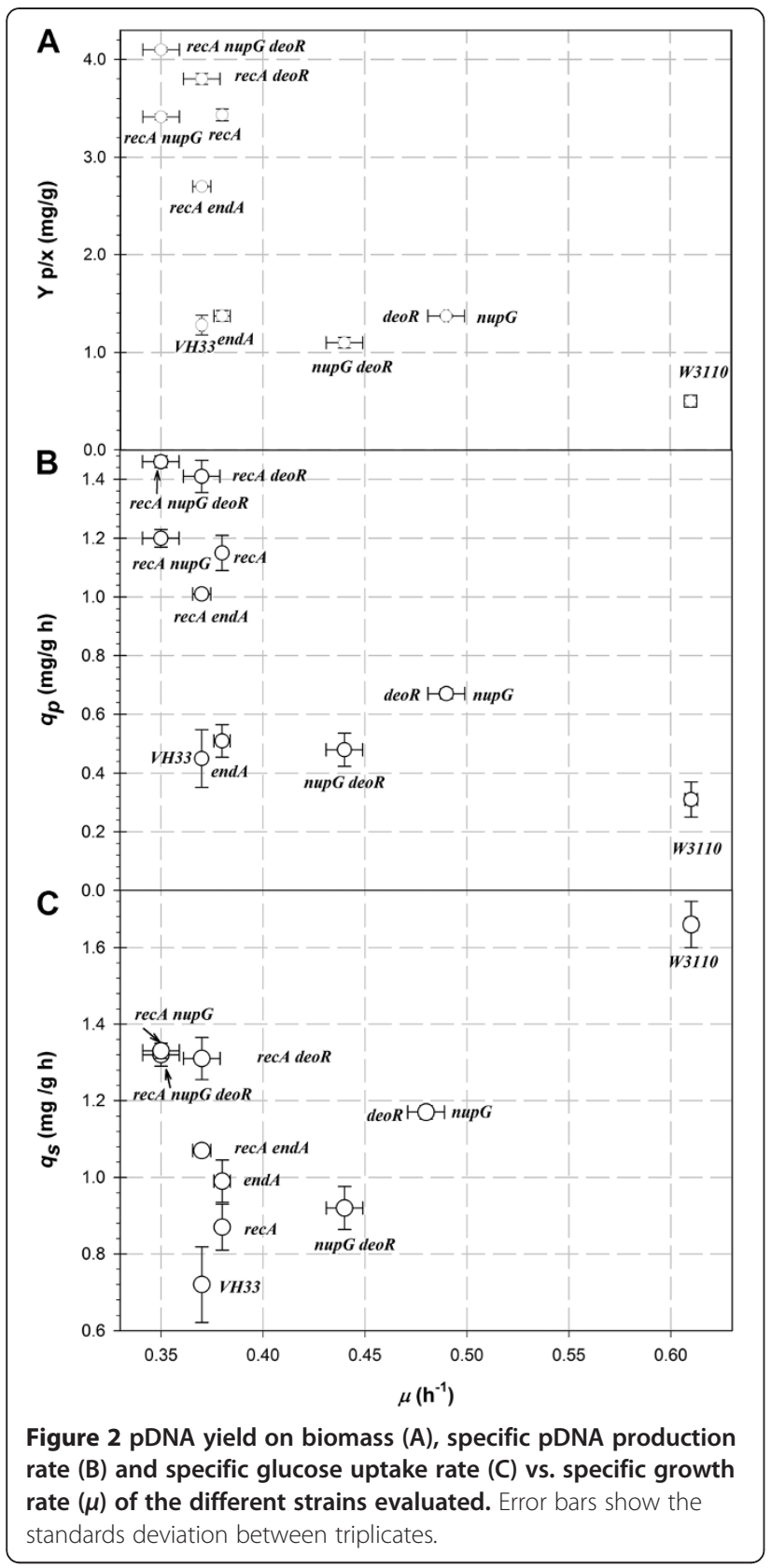

and its $\mathrm{Y}_{\mathrm{p} / \mathrm{x}}$ value was 2.4 times higher than that of W3110. Notwithstanding the higher $\mu$ of W3110, its $q_{p}$ value was much lower than that of VH33 (Figure 2B). The important difference in specific glucose consumption rate $\left(q_{s}\right)$ (Figure 2C) is in agreement with the molecular design of VH33 to reduce overflow metabolism. The deletion of genes related to nucleotide catabolism increased the growth rate of $\mathrm{VH} 33$ (up to $32 \%$ in the case of $\mathrm{VH} 33 \Delta$ deoR), whereas $Y_{p / x}$ remained relatively unchanged (Figure $2 \mathrm{~A}$ ), which in turn resulted in a decrease of $q_{p}$ (Figure 2B) and was accompanied by a large increase of $q_{S}$ (Figure $2 \mathrm{~B}$ ). Due to the fact that the biomass yield in glucose $\left(\mathrm{Y}_{\mathrm{x} / \mathrm{s}}\right)$ did not change for these mutants compared to VH33 (data not shown), it could be hypothesized that glucose was consumed faster in order to synthesize more nucleotides, but it was not reflected in an increase of pDNA production since the regulation of plasmid replication is still present as recA gene was not deleted in this strain. As described earlier, the most important changes were seen when $r e c A$ gene was deleted from VH33. The sole deletion of recA had a slight effect on growth rate but increased $Y_{p / x}$ in 283\%. Consequently, $q_{p}$ increased considerably, compared to $\mathrm{VH} 33$ (from $0.45 \pm 0.05$ to $1.15 \pm 0.09 \mathrm{mg} / \mathrm{g} \mathrm{h}$ ) (Figure $2 \mathrm{~A}-\mathrm{B}$ ). Interestingly, $q_{s}$ changed slightly as a result of this mutation (Figure 2C), but $\mathrm{Y}_{\mathrm{x} / \mathrm{s}}$ decreased from $0.52 \pm 0.01$ to $0.43 \pm 0.01 \mathrm{~g} / \mathrm{g}$, suggesting that more carbon was directed to energy generation necessary for pDNA synthesis.

Although the double mutants VH33 $\Delta$ (recA deoR) and VH33 $\Delta$ (recA nupG) did not produce more pDNA than the single mutant VH33 $\Delta(\operatorname{rec} A)$, they consumed glucose faster than the other mutants (Figure 2B), probably by the same reason that was proposed above. Slightly higher $Y_{p / x}$ values were observed for the double mutants compared to VH33 $\Delta$ (recA). However, the $\mathrm{Y}_{\mathrm{x} / \mathrm{s}}$ of the double mutants were also slightly lower (9\%) than for VH33 $\Delta$ (recA) (data not shown), which explains the unchanged final pDNA concentration. Nevertheless, the $q_{p}$ values of these mutants, particularly VH33 $\Delta$ ( recA deoR) was higher than that of VH33 $\Delta(\operatorname{rec} A)$. Finally the triple mutant reached the highest $\mathrm{Y}_{\mathrm{p} / \mathrm{x}}(4.12 \pm 0.20 \mathrm{mg} / \mathrm{g})$ and $q_{p}(1.46 \pm 0.10 \mathrm{mg} / \mathrm{g} \mathrm{h})$ values of all the mutant strains. Based on these results, the triple mutant strains VH33 $\Delta$ (recA deoR nup $G)$ was selected for evaluation in high cell-density cultivations in batch mode.

\section{Cultivation in small-scale bioreactors}

The performance of strain VH33 $\Delta$ (recA deoR nupG) under well defined conditions was evaluated in smallscale bioreactors. Such experiments allowed the attainment of high cell-densities in batch mode, something that cannot be achieved in shake flask due to the lack of $\mathrm{pH}$ and dissolved oxygen tension control. Two groups of cultivations were carried out: using low $(5 \mathrm{~g} / \mathrm{L})$ and high $(100 \mathrm{~g} / \mathrm{L})$ initial glucose concentrations. For comparison, the commercial strain DH5 $\alpha$ was cultivated under the same conditions. Results of cultivations using low initial glucose concentration can be seen in Figure 3. The results of bioreactor cultivation using $5 \mathrm{~g} / \mathrm{L}$ of initial glucose are similar to those of shake flask: DH $5 \alpha$ strain produced $13.09 \pm 0.34 \mathrm{mg} / \mathrm{L}$ of pDNA and $0.66 \pm 0.02 \mathrm{~g} / \mathrm{L}$ of acetate, which started to accumulate $4 \mathrm{~h}$ after inoculation (Figure 3A). The pDNA supercoiled fraction was nearly constant and higher than $80 \%$, and the $Y_{p / x}$ value also remained relatively constant between $5-6 \mathrm{mg} / \mathrm{g}$ (Figure 3A). VH33 $\Delta$ (recA deoR nup G) produced $8.8 \pm 0.22 \mathrm{mg} / \mathrm{L}$ of pDNA while maintaining a supercoiled fraction close to $80 \%$ and a relatively constant $\mathrm{Y}_{\mathrm{p} / \mathrm{x}}$ of 


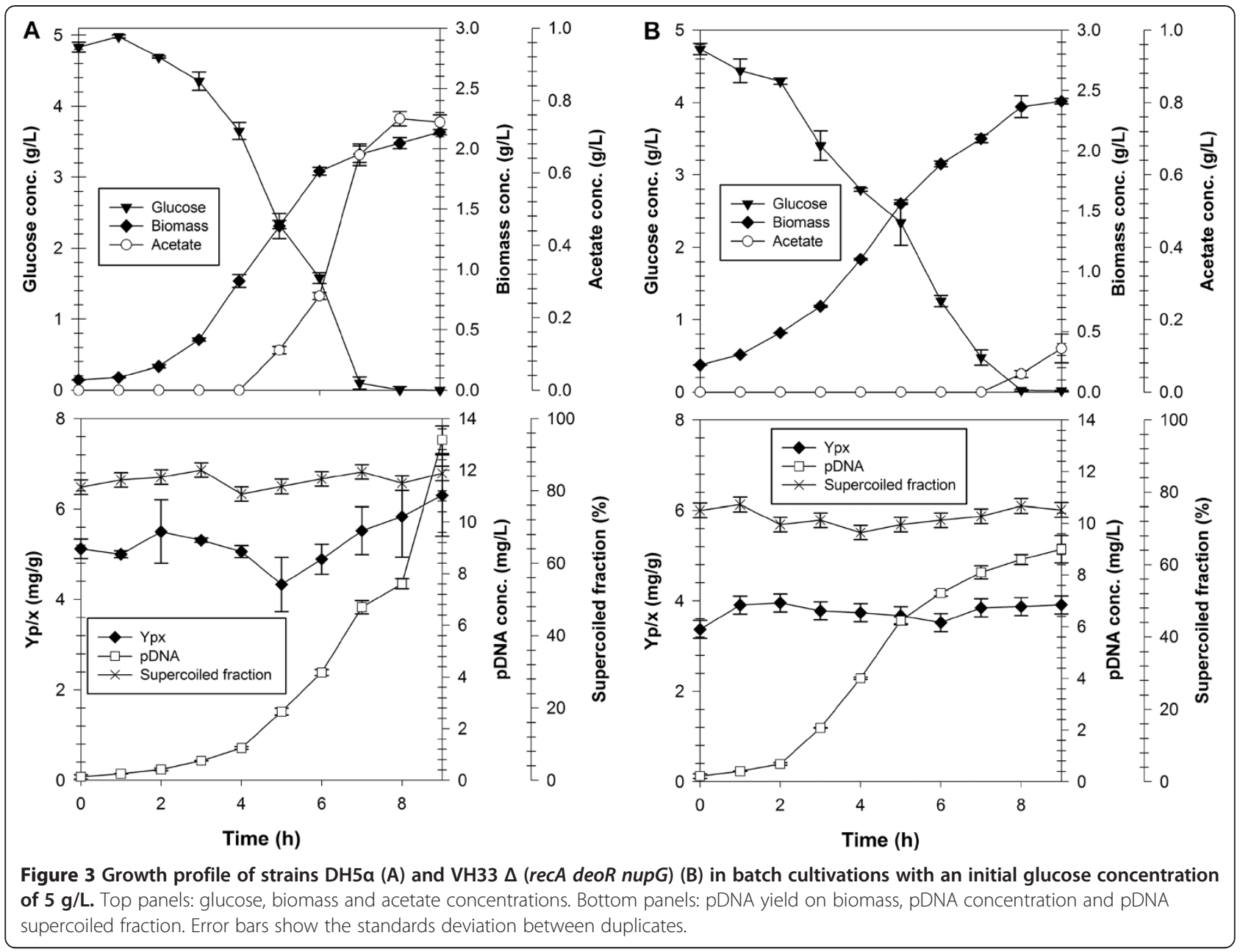

around $4 \mathrm{mg} / \mathrm{g}$ (Figure 3B). This latter result is interesting since previous results of $\mathrm{VH} 33$ showed a decrease of $\mathrm{Y}_{\mathrm{p} / \mathrm{x}}$ throughout the batch cultivation [20]. The plasmid stability in the triple mutant strain is an additional advantage provided by the deletion of $r e c A$. However, pDNA production was higher in $\mathrm{DH} 5 \alpha$ cultivations under low glucose concentrations.

The second group of cultivations aimed at attaining high cell-densities in batch mode using an initial glucose concentration of $100 \mathrm{~g} / \mathrm{L}$. The growth profile of DH5 $\alpha$ at $100 \mathrm{~g} / \mathrm{L}$ of initial glucose is shown in Figure 4A. As it can be seen, acetate accumulated up to $9.5 \pm 0.8 \mathrm{~g} / \mathrm{L}$. The growth rate was only $0.17 \pm 0.02 \mathrm{~h}^{-1}$, which means a decrease of more than $60 \%$ compared to conditions of low glucose concentration. Growth ceased at $18 \mathrm{~h}$, when acetate concentration was around $9 \mathrm{~g} / \mathrm{L}$ and glucose concentration was still above $10 \mathrm{~g} / \mathrm{L}$. Growth cessation can be attributed to the elevated acetate concentration, which is known to be toxic for E. coli at concentrations of $5 \mathrm{~g} / \mathrm{L}$ [34]. In consequence, $\mathrm{Y}_{\mathrm{x} / \mathrm{s}}$ was only $0.19 \pm 0.03 \mathrm{~g} / \mathrm{g}$, which represented a decrease of $50 \%$ compared to low glucose concentration cultivations. The pDNA supercoiled fraction was not affected by these conditions (Figure 4A), but the $\mathrm{Y}_{\mathrm{p} / \mathrm{x}}$ value was approximately $30 \%$ lower than cultivations with $5 \mathrm{~g} / \mathrm{L}$ of glucose and decreased throughout the cultivation (Figure 4A). As a result of the low yields and high acetate accumulation, the pDNA produced by $\mathrm{DH} 5 \alpha$ reached only $70 \pm 4 \mathrm{mg} / \mathrm{L}$ (Figure $4 \mathrm{~A}$ ).

As shown in Figure 4B, strain VH33 $\Delta$ (recA deoR $n u p G)$ produced a relatively low amount of acetate $(2.2 \pm 0.1 \mathrm{~g} / \mathrm{L})$, as expected from its engineered glucose transport system. Noticeably, the specific growth rate decreased to $\left(0.15 \pm 0.02 \mathrm{~h}^{-1}\right)$, which is a reduction of nearly $50 \%$ compared to conditions of low glucose concentration. Such a decrease in growth rate has been observed before [18-20,35] and attributed to the elevated osmolality of the highly concentrated medium. Also, $\mathrm{Y}_{\mathrm{x} / \mathrm{s}}$ decreased to $0.40 \pm 0.03 \mathrm{~g} / \mathrm{g}$, which represented a reduction of around $17 \%$ with respect to low glucose conditions. Yet, high cell-densities were attained, since biomass reached a concentration of $40 \mathrm{~g} / \mathrm{L}$. Additionally, the pDNA supercoiled fraction was not significantly affected by these cultivation conditions, since it remained relatively constant at around $75 \%$ throughout the cultivation (Figure $4 \mathrm{~B}$ ). In 

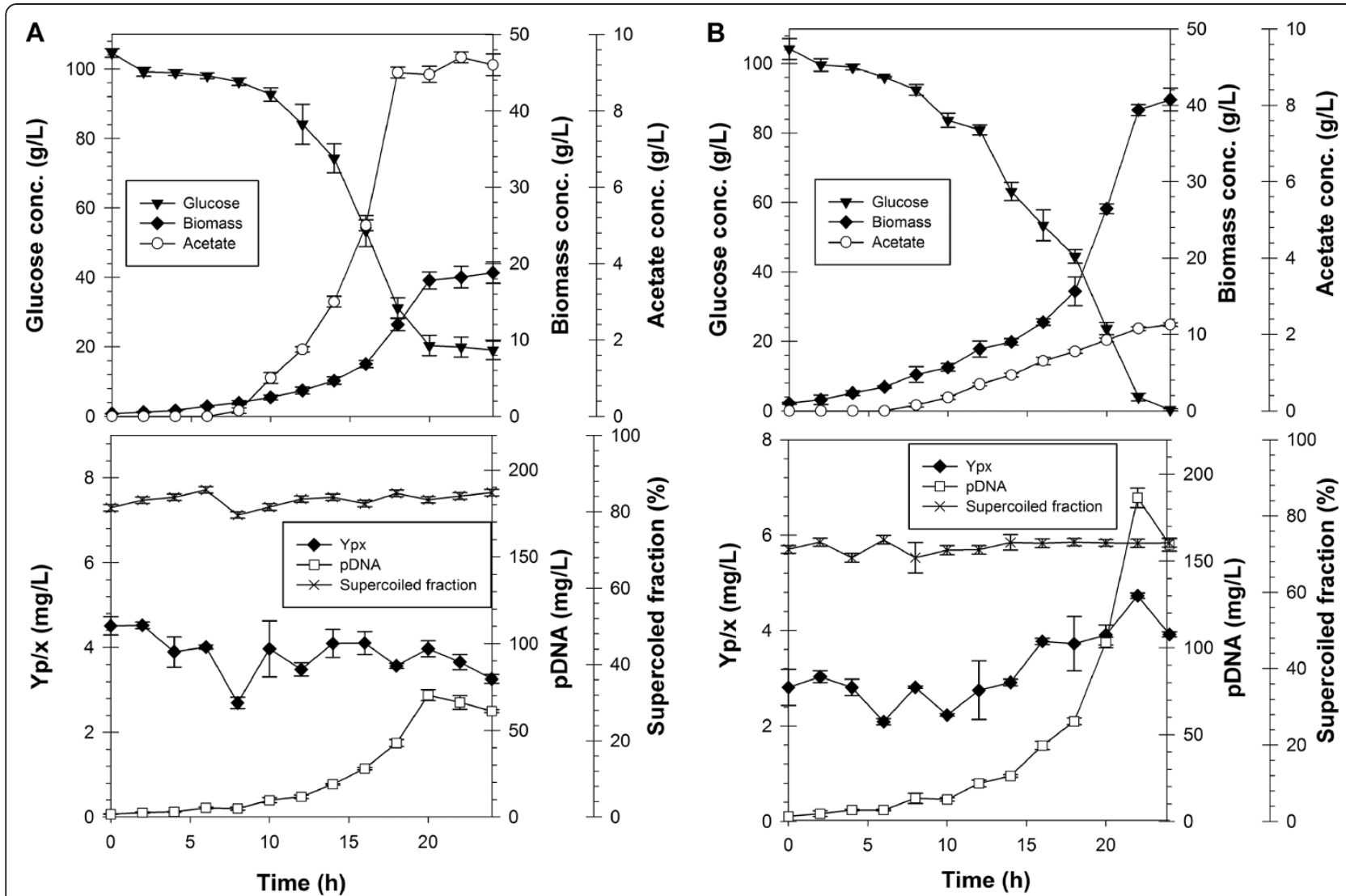

Figure 4 Growth profile of strains $\mathrm{DH} 5 \mathrm{a}(\mathrm{A})$ and $\mathrm{VH} 33 \Delta$ (recA deoR nupG) (B) in batch cultivations with an initial glucose concentration of $100 \mathrm{~g} / \mathrm{L}$. Top panels: glucose, biomass and acetate concentrations. Bottom panels: pDNA yield on biomass, pDNA concentration and pDNA supercoiled fraction. Error bars show the standards deviation between duplicates.

contrast, the $Y_{\mathrm{p} / \mathrm{x}}$ was close to $3 \mathrm{mg} / \mathrm{g}$ during the first $15 \mathrm{~h}$ of cultivation, and increased thereafter to around $4 \mathrm{mg} / \mathrm{g}$ until the end of the batch, probably due to a decreased osmotic stress due to the lower glucose concentration $(60 \mathrm{~g} / \mathrm{L}$ from $15 \mathrm{~h})$. As a result of the most favorable growth performance, compared to DH5 $\alpha$ cultivations (less acetate accumulated), the maximum pDNA concentration reached by VH33 $\Delta$ (recA deoR nup G) was $186 \pm 15 \mathrm{mg} / \mathrm{L}$. Such pDNA concentration is, to the best of our knowledge, the highest ever reported for a batch cultivation of E. coli. Some of the highest pDNA concentrations reported for batch mode, are shown in Table 1. As it can be seen, the two highest concentrations attained prior to the present work, employed cultures with very rich media that can either sensibly increase production costs (in the case of amino acids and nucleotide additions) or reduce the reproducibility of the process and generate a considerable amount of foam (in the case of complex media),

Table 1 Some of the highest pDNA concentrations reached in batch cultivations

\begin{tabular}{|c|c|c|c|c|}
\hline Reference & Strain used & Cultivation medium & $\begin{array}{l}\text { Carbon source } \\
\text { (concentration) }\end{array}$ & $\begin{array}{l}\text { pDNA concentration } \\
\text { reached }(\mathrm{mg} / \mathrm{L})\end{array}$ \\
\hline [36] & $\mathrm{DH} 5 \mathrm{a}$ & Defined, supplemented with glutamate & Glycerol (52 g/L) & 45 \\
\hline$[37]$ & JM109 & $\begin{array}{c}\text { Defined, supplemented with } 20 \text { aminoacids and } \\
\text { nucleotides }\end{array}$ & Glucose (5 g/L) & 60 \\
\hline$[38]$ & HB101 & $\begin{array}{l}\text { Complex, supplemented with yeast extract, } \\
\text { casaminoacids, torula yeast RNA and RNase A }\end{array}$ & Glucose (20 g/L) & 109 \\
\hline [39] & $\mathrm{DH} 5 \mathrm{a}$ & $\begin{array}{l}\text { Complex, supplemented with casein peptone and yeast } \\
\text { extract }\end{array}$ & $\begin{array}{l}\text { Sucrose }(10 \mathrm{~g} / \mathrm{L}) \text { and } \\
\text { glycerol }(10 \mathrm{~g} / \mathrm{L})\end{array}$ & 52 \\
\hline$[20]$ & $\mathrm{VH} 33$ & Mineral & Glucose $(100 \mathrm{~g} / \mathrm{L})$ & 40 \\
\hline This work & VH33 $\Delta$ (recA deoR nup $)$ & Mineral & Glucose (100 g/L) & 186 \\
\hline
\end{tabular}


Table 2 Sequences of the oligonucletides used for chromosomal inactivation

\begin{tabular}{|c|c|c|}
\hline Gen & Oligonucleotide & $5^{\prime}-3^{\prime}$ Sequence \\
\hline recA & recA1 & GTTGCGGCCTAAAGAGACATCTACTCTCGCTTCCGCATCG-ATGGGAATTAGCCATGGTCC \\
\hline recA & recA2 & CAACAGAACATATTGACTATCCGGTATTACCCGGCATGAC-TGTAGGCTGGAGCTGCTTCG \\
\hline endA & endA1 & AAGCGCGTTGCACATACGGGTTATGATTGCCCTGCACCTT-CATGGGAATTAGCCATGGTC \\
\hline endA & endA2 & GGCCCGGCGTTGGCCGAAGGTATCAATAGTITTTCTCAGG-TGTAGGCTGGAGCTGCTTCG \\
\hline nupG & nupG1 & ATGTGCTTITTCAAACACTCATCCGCATCACGATGTGAGG-TGTAGGCTGGAGCTGCTTCG \\
\hline nupG & nupG2 & TTGAACATCGCCATGAACGCGAAGGCCAGAACCACGGAGT-ATGGGAATTAGCCATGGTCC \\
\hline $\operatorname{deo} R$ & deoR1 & CACGTCGCGAAGAGCGTATCGGGCAGCTGCTGCAAGAATT-TGTAGGCTGGAGCTGCTTCG \\
\hline $\operatorname{deoR}$ & deoR2 & TTACTGTGGTCGACAACCAGCACATGCTTTTGCGCCATC-ATGGGAATTAGCCATGGTCC \\
\hline
\end{tabular}

which can be an important concern in large-scale cultivations. If pDNA yields of VH33 $\Delta$ (recA deoR nupG) were to be improved, simple additions to the used media, such as glutamate or casaminoacids would be a simple alternative. Additional cell engineering strategies could also be implemented to improve pDNA production.

\section{Conclusions}

Cultivation of the engineered strain VH33 $\Delta$ (recA deoR $n u p G)$ using high glucose concentrations allowed the attainment of high cell-densities in batch mode and the production of high amounts of pDNA. Further strategies are needed to reduce some undesired effects of high glucose-concentrations, like the reduction in yields and growth rate. Overall, the present study represent a useful option to avoid, through cell engineering strategies, traditional cultivation problems such as overflow metabolism and presence of substrate gradients.

\section{Materials and methods}

\section{E. coli strains and plasmids}

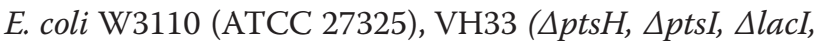
lacZ::loxP), DH5 $\alpha$ (endA1, recA1, gyrA96, thi, hsdR17, relA1, supE44, $\Delta$ lacU169, Ф80, lacZ $\Delta \mathrm{M} 15)$ and P1 vir phage where laboratory collection material. For assessment of pDNA production, a $6.1 \mathrm{~kb}$ plasmid named $\mathrm{pHN}$ was used. Plasmid $\mathrm{pHN}$ was constructed from the pcDNA3.1(+) plasmid (Invitrogen), which contains the pUC origin of replication and an ampicillin resistance gene. A viral haemagglutinin-neuraminidase gene was cloned under transcriptional control of the cytomegalovirus promoter. $\mathrm{pHN}$ plasmid is being evaluated as a DNA vaccine against mumps in humans [40].

\section{Gene deletions}

Gene knock-outs were carried out by recombination using plasmid pKD46 as previously described [41]. Chloramphenicol markers in plasmids were amplified by PCR to knock out endA, recA, nupG and $\operatorname{deoR}$ genes, respectively, and are reported in Table 2. PCR products carrying antibiotic markers and homologous region
(40 bp) were electroporated into $E$. coli W3110 carrying pKD46 where lambda recombinase was fully induced by growth on L-arabinose during cultivation at $30^{\circ} \mathrm{C} .2 \mathrm{~h}$ after electroporation and incubation at $37^{\circ} \mathrm{C}$, cells were spread on LB agar plates containing chloramphenicol (30 mg/mL). Among candidate colonies, specific gene disruptions were identified by PCR with primers which can hybridize upstream or downstream of deleted endA, $\operatorname{rec} A$, nup $G$ and deoR genes, respectively. The primers sequences are depicted in Table 3 . The disrupted genes, carrying the drug markers, were transferred to VH33 strain by standard P1 transduction [42]. Gene disruptions in the VH33 strain were reconfirmed by PCR.

\section{Cultivation media}

Cultivation medium had the following composition (in $\mathrm{g} / \mathrm{L}$ ): $\mathrm{K}_{2} \mathrm{HPO}_{4}, 17 ; \mathrm{KH}_{2} \mathrm{PO}_{4}, 5.3 ;\left(\mathrm{NH}_{4}\right)_{2} \mathrm{SO}_{4}, 2.5 ;\left(\mathrm{NH}_{4}\right) \mathrm{Cl}, 1$; sodium citrate, $1 ; \mathrm{MgSO}_{4} \cdot 7 \mathrm{H}_{2} \mathrm{O}, 1$; ampicillin disodium salt, 0.1 ; thiamine hydrochloride, 0.01 and $2 \mathrm{~mL}$ of a stock solution of trace elements [20] per L of medium. The medium was supplemented with 5 or $100 \mathrm{~g} / \mathrm{L}$ of glucose, which was sterilized separately and added to the cold medium. For shake flasks cultivations, 3-(N-morpholino) propanesulfonic acid (MOPS) was added as a buffer at a final concentration of $20 \mathrm{mM}$. Ampicillin disodium salt $(0.1 \mathrm{~g} / \mathrm{L})$ was used as selective pressure in all shake flask and bioreactor cultivations.

Table 3 Sequences of the oligonucleotides used for chromosomal insertions comprobation

\begin{tabular}{|c|c|c|}
\hline Gen & Oligonucleotide & $5^{\prime}-3^{\prime}$ sequence \\
\hline recA & recA1 & ATGGGAATTAGCCATGGTCC \\
\hline $\operatorname{rec} A$ & recA2 & TGTAGGCTGGAGCTGCTTCG \\
\hline end $A$ & endA1 & CGTGGCTGACCAGCTCATCT \\
\hline end $A$ & endA2 & TGCAGGTCGCTTCACGACTC \\
\hline nupG & nupG1 & CTTCGCGGATTATCTGCTGA \\
\hline nupG & nupG2 & GTGGCAGGATTATCCGACAT \\
\hline $\operatorname{deo} R$ & deoR1 & GTCCGGTAATGACGCCTGTA \\
\hline $\operatorname{deo} R$ & deoR2 & CAACGACTTGCCTGTATTGG \\
\hline
\end{tabular}




\section{Precultures development}

Cryo-preserved E. coli cells were cultivated in $250 \mathrm{~mL}$ baffled shake flasks containing $50 \mathrm{~mL}$ of the described medium, including $0.1 \mathrm{~g} / \mathrm{L}$ of ampicillin disodium salt and $5 \mathrm{~g} / \mathrm{L}$ of glucose. Precultures were maintained at $37^{\circ} \mathrm{C}$ and $200 \mathrm{rpm}$ in an orbital shaker for $18 \mathrm{~h}$. Cells were taken during exponential growth phase, and $100 \mathrm{~mL}$ of the preculture were centrifuged at $4000 \mathrm{rpm}$ for $10 \mathrm{~min}$ at $4^{\circ} \mathrm{C}$. The resulting pellet was resuspended in $10 \mathrm{~mL}$ of fresh mineral medium and this concentrated biomass was used to inoculate a $3 \mathrm{~L}$ bioreactor. The initial biomass concentrations for low cell-density cultivations $(5 \mathrm{~g} / \mathrm{L}$ of initial glucose) were $0.25 \pm 0.1 \mathrm{~g} / \mathrm{L}$. In the case of high cell-density cultivations the initial biomass concentration were $2.0 \pm 0.2 \mathrm{~g} / \mathrm{L}$.

\section{Shake flask cultivations}

Shake flasks cultivations were conducted at $37^{\circ} \mathrm{C}$ and $200 \mathrm{rpm}$ in an orbital shaker. Samples for glucose and acetate analyses were taken every h. Samples for pDNA analyses were taken at glucose exhaustion. All the cultivations were performed by triplicate. The final $\mathrm{pH}$ was above 6.8 for all the cultivations.

\section{Bioreactor cultivation}

E. coli strains were cultivated in a BioFlo 110 Modular Fermentor System (New Brunswick Scientific, Edison, NJ) using a set of $3 \mathrm{~L}$ bioreactors. A working volume of $1.6 \mathrm{~L}$ was used. AFS-Biocommand Bioprocessing Software (New Brunswick Scientific) was used for data logging and operational parameters control. Temperature was set at $37^{\circ} \mathrm{C}$ and dissolved oxygen tension (DOT) was maintained above $30 \%$ with respect to air saturation by increasing stirrer speed (from 200 to $900 \mathrm{rpm}$ ) and enriching air with pure oxygen in order to ensure fully aerobic conditions. In addition, gas flow rate was manually varied from 0.75 to $2 \mathrm{vvm}$ when necessary to contend with the high oxygen demand in batch cultures. A $15 \% \mathrm{NH}_{4} \mathrm{OH}$ solution was used to control $\mathrm{pH}$ to 7.2. Silicone-based antifoaming agent was added on demand. All batch cultures were followed until glucose depletion. All batch cultivations were run by duplicate.

\section{Analytical methods}

Acetate concentration was determined by HPLC as previously described [18]. Glucose concentration was determined off-line with an YSI 2700 biochemical analyzer (Yellow Springs Instruments, Yellow Springs, $\mathrm{OH})$. Dry cell weights were obtained from cells pellet samples dried at $65^{\circ} \mathrm{C}$ for at least $18 \mathrm{~h}$. pDNA was extracted from $2 \mathrm{mg}$ of wet biomass using the Qiagen Spin Mini Prep kit (Hilden, Germany), following the instructions of the manufacturer and eluting the pDNA in $70 \mu \mathrm{L}$ of $\mathrm{TE}$ buffer at $70^{\circ} \mathrm{C}$. DNA concentration was measured spectrophotometrically at $260 \mathrm{~nm}$ using a Nanodrop UV spectrophotometer ND-1000 (NanoDrop, Willmington, DE). The pDNA supercoiled fraction was analyzed by image analyses of agarose gels electrophoresis as described earlier [20].

\section{Competing interests}

The authors declare that they have no competing interests.

\section{Authors' contributions}

GMB and EMM carried out the mutations. GMB also carried out the cultivation experiments. BB, GG and OTR contributed to the design of experiments and interpretation of data. ARL conceived the study, participated in its design and coordination and in the drafting of the manuscript. All the authors read and approved the final manuscript.

\section{Acknowledgements}

This work was supported by CONACyT grants 84447 and 126663, PROMEP 47410089 and DGAPA-UNAM IN203212.

\section{Author details}

'Departamento de Medicina Molecular y Bioprocesos, Col. Chamilpa, CP 62210, Cuernavaca, Morelos, Mexico. ${ }^{2}$ Departamento de Ingeniería Celular y Biocatálisis, Instituto de Biotecnología, Universidad Nacional Autónoma de México, Avenida Universidad 2001, Col. Chamilpa, CP 62210, Cuernavaca, Morelos, Mexico. ${ }^{3}$ Departamento de Microbiología, Escuela Nacional de Ciencias Biológicas, Instituto Politécnico Nacional, Prol. de Carpio y Plan de Ayala s/n, Col. Santo Tomás, CP 11340, Del. Miguel Hidalgo México, DF, Mexico. ${ }^{4}$ Departamento de Procesos y Tecnología, Universidad Autónoma Metropolitana-Cuajimalpa, Artificios No. 40, Col. Miguel Hidalgo, Del. Álvaro Obregón, México, DF CP 01120, México.

Received: 19 June 2012 Accepted: 10 September 2012 Published: 19 September 2012

\section{References}

1. Lara AR, Ramírez OT: Plasmid DNA production for therapeutic applications. In Recombinant Gene Expression, Methods in Molecular Biology, Volume 824. 3rd edition. Edited by Lorence A. New York: Humana Press; 2012:271-303. part 2.

2. Lara AR, Knabben I, Caspeta L, Sassi J, Ramírez OT, Büchs J: Comparison of oxygen enriched air vs pressurized cultivations to increase oxygen transfer and to scale-up plasmid DNA production fermentations. Eng Life Sci 2011, 11(4):382-386.

3. Carnes AE, Hodgson CP, Williams JA: Inducible Escherichia coli fermentation for increased plasmid DNA production. Biotechnol Appl Biochem 2006, 45:155-166.

4. O'Kennedy RD, Baldwin C, Keshavarz-Moore E: Effects of growth medium selection on plasmid DNA production and initial processing steps. $J$ Biotechnol 2000, 76:175-183.

5. Listner K, Bentley L, Okonkowski J, Kistler C, Wnek R, Caparoni A, Junker B, Robinson D, Salmon P, Chartrain M: Development of a highly productive and scalable plasmid DNA production platform. Biotechnol Prog 2006, 22:1335-1345.

6. Cooke JR, McKie EA, Ward JM, Keshavarz-Moore E: Impact of intrinsic DNA structure on processing of plasmids for gene therapy and DNA vaccines. J Biotechnol 2004, 114:239-254.

7. Rozkov A, Avignone-Rossa CA, Ertl PF, Jones P, O'Kennedy RD, Smith JJ, Dale JW, Bushell ME: Characterization of the metabolic burden on Escherichia coli $\mathrm{DH} 1$ cells imposed by the presence of a plasmid containing a gene therapy sequence. Biotechnol Bioeng 2004, 88:909-915.

8. Huber H, Pacher C, Necina R, Kollmann F, Reinisch C: Method for producing plasmid DNA on a manufacturing scale by fermentation of the Escherichia coli K-12 strain JM108. World Patent WO/2005/098002; 2005.

9. Singer A, Eiteman MA, Altman E: DNA plasmid production in different host strains of Escherichia coli. J Ind Microbiol Biotechnol 2009, 36:521-530.

10. Lahijani R, Hulley G, Soriano G, Horn NA, Marquet M: High-yield production of pBR322-derived plasmids intended for human gene therapy by employing a temperature-controllable point mutation. Hum Gene Ther 1996, 7:1971-1980. 
11. Yau SY, Keshavarz-Moore E, Ward J: Host strain influences on supercoiled plasmid DNA production in Escherichia coli: Implications for efficient design of large scale processes. Biotechnol Bioeng 2008, 101:529-544.

12. Gonçalves GAL, Bower DM, Prazeres DMF, Monteiro GA, Prather KLJ: Rational engineering of Escherichia coli strains for plasmid biopharmaceutical manufacturing. Biotechnol J 2012, 7(2):251-261.

13. Lara AR: Recombinant protein production in Escherichia coli. Rev Mex Ing Quim 2011, 10(2):209-223.

14. Wolfe AJ: The acetate switch. Microbiol Mol Biol Rev 2005, 69(1):12-50.

15. Lara AR, Galindo E, Ramírez OT, Palomares AL: Living with heterogeneous bioreactors: Understanding the effect of environmental gradients on cells. Mol Biotechnol 2006, 34:355-381.

16. Lara AR, Taymaz-Nikerel H, van Gulik W, Heijnen JJ, Ramírez OT, van Winden W: Fast dynamic response of Escherichia coli fermentation metabolism to aerobic and anaerobic glucose pulses. Biotechnol Bioeng 2009, 104: 1153-1161.

17. Sunya S, Delvigne F, Uribelarrea JL, Molina-Jouve C, Gorret N: Comparison of the transient responses of Escherichia coli to a glucose pulse of various intensities. Appl Microbiol Biotechnol, . in press.

18. Lara AR, Caspeta L, Gosset G, Bolívar F, Ramírez OT: Utility of an Escherichia coli strain engineered in the substrate uptake system for improved culture performance at high glucose and cell concentrations: an alternative to fed-batch cultures. Biotechnol Bioeng 2008, 99:893-901.

19. Knabben I, Regestein L, Marquering F, Steinbusch S, Lara AR, Büchs J: High cell-density processes in batch mode of a genetically engineered Escherichia coli strain with minimized overflow metabolism using a pressurized bioreactor. J Biotechnol 2010, 150:73-79.

20. Soto R, Caspeta L, Barrón BL, Gosset G, Ramírez OT, Lara AR: High celldensity cultivation in batch mode for plasmid DNA vaccine production by a metabolically engineered $E$. coli strain with minimized overflow metabolism. Biochem Eng J 2011, 56(3):165-171.

21. Pablos TE, Soto R, Meza E, Le Borgne S, Gosset G, Ramírez OT, Lara AR: Enhanced production of plasmid DNA by engineered Escherichia coli strains. J Biotechnol 2012, 158:211-214.

22. Phue JN, Lee SJ, Trinh L, Shiloach J: Modified Escherichia coli B (BL21), a superior producer of plasmid DNA compared with Escherichia coli $\mathrm{K}$ (DH5a). Biotechnol Bioeng 2008, 101:831-836.

23. Williams JA, Carnes AE, Hodgson CP: Plasmid DNA vaccine vector design: impact on efficacy, safety and upstream production. Biotechnol Adv 2009, 27:353-370.

24. Smith GR: Homologous recombination in prokaryotes. Microbiol Rev 1988, 52:1-28.

25. James AA, Kolodner R: Genetic recombination of plasmids in Escherichia coli. In Mechanisms of DNA Replication and Recombination. New York: Alan R. Liss; 1983:761-772.

26. Kolodner R, Fishel RA, Howard M: Genetic recombination of bacterial plasmid DNA: effect of RecF pathway mutations on plasmid recombination in Escherichia coli. J Bacteriol 1985, 163:1060-1066.

27. Summers DK: The Biology of Plasmids. Oxford: Wiley-Blackwell; 1996.

28. James AA, Morrison PT, Kolodner R: Genetic recombination of bacterial plasmid DNA. Analysis of the effect of recombination-deficient mutations on plasmid recombination. J Mol Biol 1982, 160:411-430.

29. Kuzminov A: Recombinational repair of DNA damage in Escherichia coli and bacteriophage lambda. Microbiol Mol Biol Rev 1999, 63:751-813.

30. Schoenfeld T: Effects of bacterial strains carrying the endA1 genotype on DNA quality isolated with Wizard ${ }^{\circledR}$ Plasmid Purification Systems. Promega Notes 1995, 53:12-20.

31. Tse-Dinh YC, Liu IF, Sutherland JH, Cheng B: Topoisomerase I function during Escherichia coli response to antibiotics and stress enhances cell killing from stabilization of its cleavage complex. J Antimicrob Chemoth 2011, 66:1518-1524.

32. Zeng $\mathrm{XM}$, Saxild HH: Identification and characterization of a DeoR-specific operator sequence essential for induction of dra-nupC-pdp operon expression in Bacillus subtilis. J Bact 1999, 181:1719-1727.

33. Matsui H, Kawasaki H, Shimaoka M, Takenaka Y, Kurahashi O: Method for producing purine nucleoside by fermentation. US Patent: 7, 608,432 B2.; 2009.

34. Luli GW, Strohl WR: Comparison of growth, acetate production, and acetate inhibition of Escherichia coli strains in batch and fed-batch fermentations. Appl Environ Microb 1990, 56:1004-1011.

35. Chávez-Béjar MI, Lara AR, López H, Hernández-Chávez G, Martínez A, Ramírez OT, Bolívar F, Gosset G: Metabolic engineering of Escherichia coli for L-tyrosine production by the expression of the genes coding for the chorismate mutase domain from native P-protein and a cyclohexadienyl dehydrogenase from Zymomonas mobilis. Appl Environ Microbiol 2008, 74:3284-3290

36. Voß C, Schmidt T, Schleef M, Friehs K, Flaschel E: Effect of ammonium chloride on plasmid DNA production in high cell density batch culture for biopharmaceutical use. J Chem Technol Biotechnol 2004, 79:57-62.

37. Wang Z, Le GW, Shi YH, Wegrzyn G: Medium design for plasmid DNA production based on stoichiometric model. Proc Biochem 2001, 2001 (36):1085-1093.

38. Duttweiler HM, Gross DS: Bacterial growth medium that significantly increases the yield of recombinant plasmid. Biotechniques 1998, 24 (3):438-444.

39. Zheng S, Friehs K, He N, Deng X, Li Q, He Z, Xu C, Lu Y: Optimization of medium components for plasmid production by recombinant $E$. coli DH5a pUK21CMVß1.2. Biotechnol Bioproc Eng 2007, 12(3):213-221.

40. Herrera E, Barcenas P, Hernández R, Méndez A, Pérez-Ishiwara G, Barrón B: A 176 amino acid polypeptide derived from the mumps virus $H N$ ectodomain shows immunological and biological properties similar to the HN protein. Virol J 2010, 7:195.

41. Datsenko KA, Wanner BL: One-step inactivation of chromosomal genes in Escherichia coli K-12 using PCR products. Proc Natl Acad Sci USA 2000, 97:6640-6645

42. Miller JH: Experiments in Molecular Genetics. New York: Cold Spring Harbor Laboratory Press; 1972.

doi:10.1186/1475-2859-11-132

Cite this article as: Borja et al.: Engineering Escherichia coli to increase plasmid DNA production in high cell-density cultivations in batch mode. Microbial Cell Factories 2012 11:132.

\section{Submit your next manuscript to BioMed Central and take full advantage of:}

- Convenient online submission

- Thorough peer review

- No space constraints or color figure charges

- Immediate publication on acceptance

- Inclusion in PubMed, CAS, Scopus and Google Scholar

- Research which is freely available for redistribution 